\section{Michalina Kmiecik ${ }^{1}$}

Uniwersytet Jagielloński

\title{
Zapiski Aleksandra Wata z Kaiser Hospital - fragmenty autobiografii heterotopicznej
}

\begin{abstract}
Aleksander Wat's Notes from Kaiser Hospital: Fragments of a Heterotopical Autobiography
\end{abstract}

The article's purpose is to present Aleksander Wat's essay written after his stay in Kaiser Hospital in Oakland in 1964, kept in the writer's archive in the Beinecke Rare Book \& Manuscript Library in New Haven. This essay seems to be relevant for several reasons: it is a commentary to Wat's Dziennik bez samoglosek [Diary Without Vowels] and, above all, it is one of the poet's pathographic texts devoted almost entirely to an analysis of the hospital space. Using the categories of heterotopia, total institution, and infirmary, an attempt is made to describe the phenomenon of an "autobiography of the state of imprisonment" (the notes from Kaiser Hospital are treated as part of a never-written memoir My Prisons - My Hospitals) and reconstruct the poetics of a heterotopical text created from the perspective of an inhabitant of the "counter-site."

Słowa kluczowe: archiwum Aleksandra Wata, heterotopia, patografia, instytucja totalna, infirmerium

Keywords: Aleksander Wat's archive, heterotopia, pathography, total institution, infirmary

1 Stypendystka korzystająca ze wsparcia finansowego Fundacji na rzecz Nauki Polskiej (FNP). 
W oryginalnym maszynopisie Dziennika bez samogłosek przechowywanym w Beinecke Rare Book \& Manuscript Library w New Haven (Aleksander Wat Papers, Series II: Writings, Box 12, Folder 380 [GEN MSS 705]) znajdziemy następujący fragment zapisany pod datą 12 czerwca 1964:

ZATEM NIECH BEDZIE: MOJE WIEZIENIA - MOJE SZPITALE, ZSCZNE NA DOBRE OD JUTRA, ODWODNIE ZAMTOZ, I ODWODNIE JAK POTRAFY W KOSTKACH KTORE JUŻ OBAWAJA SI, BEZ FRYŻYDERYą. PRZYJALE POWIEDZA: NARESZCIE ZMAD RZAŁ I BEDA ZADOWOLENI ŻE TO SZALOWE ŻE NIE BEST SELLER A GROSSMAN POCZCIWY BEDZIE W KŁOPOCIEą

Ale to nie jest tak proste i przyjacielevtego nie rozumieją. [...)]

zastanowcie wczujcie się w moją sytuację:znow przypomnieć, ożywiś w sobie z halucynacyną wiernością takie doświadczenia już prawie ę czy pozornie zapomniane, już prwaie czy pozornie zabliżnionye ${ }^{2}$.

Dowiadujemy się z niego, że pisarz planował stworzenie prozy autobiograficznej, która miałaby rekonstruować jego doświadczenia związane z dwiema najważniejszymi dwudziestowiecznymi heterotopiami - więzieniem oraz szpitalem. Nie bez powodu Wat te dwie przestrzenie traktuje komplementarnie; o ile bowiem w zapisach dziennikowych z listopada 1963 roku nadmieniał, że w planach ma publikację pierwszej części wspomnień zatytułowanej 11 więzień, o tyle niecały rok później modyfikuje definicję doświadczenia zamknięcia. Swoją biografię wciąż postrzega w kategoriach traumatyzującej izolacji, jednak obok zainteresowań politycznym losem dwudziestowiecznego sympatyka komunizmu, chce umieścić zapisy człowieka poddanego izolacji dużo głębszej - wyobcowaniu i samotności odczuwalnym w głębi własnego ciała.

Zwrot w myśleniu Wata ma - moim zdaniem - dwojakie przyczyny. Po pierwsze, sama praca nad Dziennikiem bez samogłosek i Moim wiekiem sprawia, że pisarz zaczyna dostrzegać nieusuwalne sprzężenie pomiędzy doświadczeniem opresywności systemu totalitarnego (i własnej przeszłości komunistycznej) a późniejszą dominacją choroby bólowej. W Moim wieku wprost mówi do Czesława Miłosza:

${ }^{2} \mathrm{~W}$ wersji poprawionej, pozbawionej błędów literowych i gramatycznych, przy zachowaniu Watowskiej składni i narzuconego przez pisarza toku wypowiedzi, a także specyfiki leksykalnej, fragment ten brzmi: „ZATEM NIECH BĘDZIE: MOJE WIĘZIENIA - MOJE SZPITALE, ZACZNĘ NA DOBRE OD JUTRA, ODWODNIĘ ZAMRÓZ, I ODWODNIĘ JAK POTRAFIĘ W KOSTKACH KTÓRE JUŻ OBAWIAJĄ SIĘ, BEZ FRYŻYDERY. PRZYJACIELE POWIEDZĄ: NARESZCIE ZMĄDRZAŁ I BĘDĄ ZADOWOLENI ŻE TO SZALONE ŻE NIE BESTSELLER A GROSSMAN POCZCIWY BĘDZIE W KŁOPOCIE.

Ale to nie jest tak proste i przyjaciele tego nie rozumieją. [...] zastanówcie wczujcie się w moją sytuację: znów przypomnieć, ożywić w sobie z halucynacyjną wiernością takie doświadczenia już prawie czy pozornie zapomniane, już prawie czy pozornie zabliźnione". 
Całe moje zbliżenie się do idei komunizmu, cała moja bliskość do idei to właściwie związek demoniczny, który dał swoje owoce dopiero dzisiaj, w postaci mojej choroby3.

Wyznania eksa! Będę miał prawdopodobnie tę tendencję, nie tylko dlatego, że to jest najłatwiejsza droga, ale ponieważ, jak ci mówię, komunizm jest dla mnie czynnikiem chorobotwórczym, diabolicznie chorobotwórczym ${ }^{4}$.

Choroba nie tylko nabiera charakteru demonicznego (co stanie się swoistym lejtmotywem Dziennika bez samogłosek), jest także karą za młodzieńcze bratanie się z komunizmem i pracę w „Miesięczniku Literackim”. Bakcyl komunizmu niejako infekuje ciało Wata, a poczucie winy staje się niemożliwym do wyegzorcyzmowania diabłem. Szpital jako miejsce najgłębszego i najbardziej dojmującego uobecniania symptomów staje się zatem pewną formą uwięzienia: miejscem, w którym demon choroby (a tym samym demon komunizmu) sprawuje władzę nad bezwolnym ciałem pacjenta. Samo ciało również ulega tutaj przekształceniu w przestrzeń infirmeryjną: jest workiem, w którym Wat zostaje zamknięty i z którego nie potrafi się wydostać ${ }^{6}$. Szpital i więzienie okazują się nierozerwalnie spojone, a wręcz tożsame: cela zyskuje tym samym potrójne znaczenie miejsca odosobnienia, szpitalnego łóżka oraz niewygody własnej somy.

Drugą przyczyną, dla której Wat decyduje się podjąć pracę nad a u t o b i o grafią heteroto pi c zną $a^{7}$,jest zaś pogłębiające się podczas pobytu w Kalifornii złe samopoczucie. W jego wyniku pisarz musi regularnie korzystać $\mathrm{z}$ amerykańskiej opieki medycznej, konkretnie leczenia w The Permanente Medical Group i jednym z jej organów: Kaiser Hospital. Dokumentacja medyczna zachowana w Beinecke nie pozwala nam $\mathrm{z}$ całą dokładnością określić dat przebywania Wata w placówkach medycznych w Oakland; wiemy jedynie, że rozpoczął on terapię neurologiczną u doktora M. Neilla Rodmana

${ }^{3}$ A. Wat, Mój wiek. Pamiętnik mówiony, t. 1, Warszawa 1990, s. 52.

${ }^{4}$ Ibidem, s. 57.

${ }^{5}$ Pojęcie przestrzeni infirmeryjnej zawdzięczam Iwonie Boruszkowskiej. Badaczka pracowała nad jego doprecyzowaniem w powstałej niedawno na Wydziale Polonistyki UJ rozprawie doktorskiej Sygnatury choroby - literatura defektu w ukraińskim modernizmie (Lesia Ukrainka, Olha Kobylańska, Wołodymyr Wynnyczenko, Mykoła Kulisz). Jej koncepcja inspirowała mnie wielokrotnie podczas moich lektur niepublikowanych tekstów Wata i stała się swoistą matrycą teoretyczną dla myślenia o jego chorobie jako konstrukcie literackim (przy uwzględnieniu jej realnego, somatycznego aspektu).

${ }^{6}$ Najbardziej znanym lirycznym świadectwem istnienia przestrzeni infirmeryjnej rozumianej jako ciało jest wiersz *** $W$ czterech ścianach mego bólu..., w którym poeta opisuje swoją somatyczność jako klatkę (celę), separującą go całkowicie od rzeczywistości. Komplementarność przestrzeni szpitala (jako miejsca funkcjonowania choroby i pacjenta) oraz więzienia wydaje się w tym tekście najściślejsza (zob. A. Wat, Poezje zebrane, oprac. A. Micińska, J. Zieliński, Kraków 1992, s. 175).

${ }^{7}$ Pojęcie to postaram się rozwinąc $\mathrm{w}$ następnym podrozdziale niniejszego artykułu, odwołując się do trzech inspirujących mnie rozpoznań: Foucaultowskiej heterotopii, Goffmanowskiej instytucji totalnej oraz przestrzeni infirmeryjnej Boruszkowskiej. 
w kwietniu 1964 roku i kontynuował ją do końca pobytu. Wcześniej jednak konsultował się z lekarzami z przychodni The Permanente Medical Group, gdyż w marcu 1964 roku otrzymał stamtąd zaświadczenie o niezdolności do pracy i konieczności długotrwałego wypoczynku, zaś zachowana identyfikacyjna karta pacjenta Oli Watowej pochodzi z lutego 1964 roku. Gdy weźmie się pod uwagę jej numer - 1306 678, to okazuje się, że została wystawiona w tym samym czasie, co analogiczna karta jej męża (nr 1306 677) ${ }^{8}$. Dodatkowo w archiwum Wata w Beinecke zachowało się 11 stronic maszynopisu opatrzonego datą 11 września 1964 roku, na których opisuje on okres swojej hospitalizacji w Kaiser Hospital. Jako że nie sposób już dotrzeć do wypisów szpitalnych (nie posiada ich ani archiwum amerykańskie, ani archiwum Biblioteki Narodowej w Warszawie), nie ustalimy, kiedy dokładnie przebywał Wat w placówce Kaisera. Mogło to jednak być mniej więcej w tym okresie, kiedy artysta zdecydował się na połączenie wspomnień więziennych i szpitalnych $\mathrm{w}$ jedną książkę. Jej jedynym zachowanym fragmentem stawałyby się tym samym wspomniane przed chwilą, nieuporządkowane notatki zatytułowane DO SKAISER HOSPITAL, które chciałabym poddać w tym artykule pogłębionej lekturze.

\section{Notatki z Kaiser Hospital a kwestia autobiografii heterotopicznej}

Mianem „notatek z Kaiser Hospital” określam 11 stron maszynopisu sporządzonego przez Wata i opatrzonego przez niego odręcznymi poprawkami oraz dopiskami, które przechowywane są w archiwum pisarza w Beinecke Library9 . Wat pisze po obu stronach kartki; tusz miejscami jest odbity bardzo słabo, dlatego niektóre litery, a nawet całe wyrazy wydają się nieczytelne. Te kilkanaście kartek można podzielić na trzy części. Pierwsza z nich, notowana na papierze o wysokiej gramaturze tuszem w kolorze niebieskim, liczy 4 stronice i kończy się zapowiedzią części kolejnej: „Ale wrośmy do Kaiser Hospital i moich tragikomicznych w nmi przgod"10. Nie występują w niej żadne korekty

\footnotetext{
${ }^{8}$ Wszystkie materiały dokumentujące chorobę Wata przechowywane są w Beinecke Library: Aleksander Wat Papers, Series III: Personal Papers and Memorabilia, Box 38, Folder 840-846 (GEN MSS 705).

${ }^{9}$ Aleksander Wat Papers, Series II: Writings, Box 28, Folder 662 (GEN MSS 705).

${ }^{10} \mathrm{~W}$ cytatach zachowuję oryginalną pisownię Wata. Tekst nie został przeze mnie poddany żadnej obróbce: to wierna kopia ortografii, składni i gramatyki używanej przez pisarza. Mimo że utrudnia to w sposób znaczący lekturę fragmentów, będzie kluczowe dla ich dalszej poetologicznej analizy. W cytatach trzymałam się następujących zasad zapisu:

Notatki z Kaiser Hospital - tekst maszynopisu;

Notatki z Kaiser Hospital - skreślenie poczynione przez Wata;

[Notatki z Kaiser Hospital] - dopisek odręczny Wata;

[?] - nieczytelny dopisek odręczny Wata.
} 
czy marginalia odautorskie. Na drugą część składają się 3 strony maszynopisu sporządzonego na papierze przebitkowym, również niebieskim tuszem. Nie pojawia się na nich nowa data (być może fragment powstał zaraz po wcześniejszym zapisie, zmienia się bowiem jedynie papier, tusz pozostaje ten sam). Na pierwszej stronie tej części znajdziemy mnóstwo skreśleń, nadpisów i dopisków marginesowych wykonanych piórem o czarnym i granatowym atramencie; następne dwie strony są ich zupełnie pozbawione. Część trzecia (4 strony maszynopisu) notowana jest na takim samym papierze i identycznym jak druga tuszem. Otwierająca ją uwaga na marginesie (, wiersz Kaiser Hospital”) świadczy jednak o tym, że została sporządzona w innym czasie i dopiero później pisarz przyporządkował ją do reszty. Rozpoczyna się zapisem liryku o incipicie *** Szanujacy się kościotrup ... ${ }^{11}$, który następnie płynnie przechodzi w prozę wspomnieniową. Dwie pierwsze kartki zostały tu z sobą zszyte; pierwsza z nich jest odręcznie przekreślona pionową i skośnymi kreskami. Marginalia i dopiski sporządzono - odmiennie niż w części drugiej - niebieskim i czerwonym długopisem oraz piórem o granatowym atramencie. Być może korekta dokonywana tym ostatnim objęła zarówno część drugą, jak i trzecią.

Ta dość pieczołowita rekonstrukcja wyglądu samego maszynopisu jest dla mnie nie bez znaczenia. Trudno bowiem ustalić, czym tak naprawdę miały być w zamyśle Wata prezentowane notatki. Dość prawdopodobną hipotezą wydaje się połączenie ich z powstającym równolegle Dziennikiem bez samogłosekwpisują się one w poetykę dziennika (zostały opatrzone datą), posługują się

Jako że nie analizuję tu szerzej zależności między maszynopisem a odręcznymi marginaliami (nie wszystkie zresztą są dla mnie czytelne ze względu na bardzo drobne i miejscami rozmazane pismo Wata), nie wprowadzam kolorystycznych rozróżnień w odnotowywaniu kolejnych „faz” korekty robionej przez pisarza. To jednak problem, który - jak sądzę - mógłby zostać badawczo wyeksploatowany.

${ }^{11}$ Oczywiście, fraza ta znajdzie się następnie w wielokrotnie modyfikowanym i wzmiankowanym też w Dzienniku bez samogłosek wierszu Skóra i śmierć, opublikowanym ostatecznie z dedykacją dla Jana Lebensteina w tomie Ciemne świecidto (zob. A. Wat, Poezje zebrane, s. 344-345). Wersja z notatek z Kaiser Hospital jest jednak skrajnie odmienna od tej, jaką znamy z książki poetyckiej Wata. Właściwie tożsama pozostaje jedynie otwierająca fraza „Szanujący się kościotrup”, która w omawianym maszynopisie znajduje zupełnie inne dopełnienie:

„Szanujący się kosciotrup nigdy nie pattrzy

na cudzą nagosc. Kiscią przykrywa oczodoł[y],

z ktorych łzy ropa łez cieknie [?]. O!

jak mnie dręczy nagosc twarzy, nagosc, [(Jakie piękne słowo polskie: ,rąk”]

nagose skory $\mathrm{n}[\mathrm{N}]$ agosc oczu, $\mathrm{f}[\mathrm{R}] \mathrm{ąk} . \mathrm{z}[\mathrm{przy}]$ muszaiłem żonę [Olę]

by wchodząc do mnie nakładał[a] maskę, kup[i]oną [dawniej] dla

smiechu w magazynie $\mathrm{p}$ sklepie potwornosci w s[S]an f[F]rancisco, $\mathrm{m}$

Wchodziła do mnie z sią [zatem] opuehniętą [z] małą twarzą [yczką] cmentarbnicy

Mrs Addams. Przyjaciel[e] nosił [moje] gkiwając[li] [?] się g [?] wodogłowę ha

houdkeepera panstwa Addams".

Po zakończeniu zdania Wat rezygnuje z rozbicia na wersy i płynnie powraca do prozy wspomnieniowej. 
podobnie agramatycznym i pełnym potknięć językiem, dotyczą choroby i stanowią w niewielkiej części komentarz do używanego w diariuszu zapisu spółgłoskowego (zwanego tu stenograficznym) ${ }^{12}$. Jednocześnie, wskazany przeze mnie podział każe wątpić w jednolitość omawianego maszynopisu i nie pozwala traktować go jako spójnego wpisu dziennego: sprawia, iż zbliża się on raczej formą do rozproszonych notatek, sporządzanych z myślą o jakiejś większej całości. Oprócz tego, jest - w przeciwieństwie do Dziennika ... - pisany bez zachowania poszerzonego lewego marginesu, który w diariuszu służył Watowi jako przestrzeń do robienia odręcznych uzupełnień. Dlatego chciałabym postawić tutaj inną hipotezę o jego przeznaczeniu: potraktować „,notatki z Kaiser Hospital” jako szkice do nigdy niepowstałej książki autobiograficznej Moje więzienia - moje szpitale.

Jeśli zdecydujemy się na taki krok, to wyjaśnimy w ten sposób nieciągły charakter maszynopisu, jego fragmentaryczną i niezborną formę: w przeciwieństwie do zapisów dziennikowych, przypomina on raczej sporządzane na maszynie pierwsze wersje esejów lub konspekty/notatki do nich. Stanowi również w swojej pierwszej części komentarz do Dziennika bez samogłosek; Wat zwierza się z niemożliwości odczytywania własnych brulionów, sugeruje użycie szyfru spółgłoskowego jako formy zapisu przyspieszonego, usprawniającego przenoszenie galopujących myśli na papier. Jednocześnie zauważa, jak bardzo niespójny i ,żaden” jest jego stenogram. Sam nie potrafi go odszyfrować i nadać mu sensu. Dochodzi więc do wniosku, że choroba odcina go od możliwości komunikacyjnych: zostaje zamknięty w somatycznej celi, z której nie tylko nie ma ucieczki ku innemu człowiekowi, ale także zerwany zostaje kontakt z dotychczasowym, świadomym ,ja”, zastąpionym przez zdezintegrowany podmiot defektywny ${ }^{13}$ :

[...] dotknięty chorobą, przez psychosomatyczne zdarzenie (dotyczące siebie lub innego) zmuszony do przeformułowania koncepcji własnego ,ja” i włączenia do swojej życiowej czasoprzestrzeni nowego czynnika - choroby. [...] W wyniku doświadczenia medycznego w wyobrażeniach o ,ja”, ciele i świecie podmiotu zachodzą zmiany, które nadają poszczególnym elementom rzeczywistości inne, nowe znaczenia. [...] W zależności od zakresu włączenia tego doświadczenia i odnalezienia się w roli „chorego” można mówić o ponownej konstrukcji tożsamości lub o dezintegracji ,ja" chorego ${ }^{14}$.

U Wata, z całą pewnością, podmiot pozostaje zawieszony w stanie rozproszenia, nieumiejętności skupienia i odnalezienia jakiegokolwiek nowego trzo-

12 Tezy o komplementarności notatek z Kaiser Hospital i Dziennika bez samogłosek rozwijam w posłowiu do przygotowywanego wydania zaszyfrowanej wersji dziennika, które powinno ukazać się w 2017 r. Uwzględni ono też przedruk notatek z Kaiser Hospital $\mathrm{w}$ formie suplementu do oryginalnego tekstu dziennika.

${ }^{13}$ Koncepcję podmiotu defektywnego rozwija Iwona Boruszkowska w swojej książce Defekty. Auto/pato/grafie - szkice, Kraków 2016.

${ }^{14}$ Ibidem, s. 16. 
nu swojej tożsamości. Przekonanie o uwięzieniu w chorobie skłania go więc najpewniej do podjęcia ważnej próby zestawienia dwóch doświadczeń heterotopii i stworzenia a u tobi ografii het erotopicznej.

Wizja szpitala i więzienia, jaka wyziera z tekstów Wata, wpisuje się oczywiście w ramy nakreślone przez Michela Foucaulta w słynnym eseju Inne przestrzenie, choć koresponduje ona także z jeszcze jednym, mocniejszym pojęciem: instytucji totalnej. Termin wprowadzony pod koniec lat pięćdziesiątych przez Ervinga Goffmana przylega bardzo dobrze do opresywnych wyobrażeń polskiego pisarza; na przykładzie notatek z Kaiser Hospital chciałabym pokazać, w jaki sposób szpital zostaje w tej prozie wspomnieniowej włączony do zbioru instytucji totalnych, choć Goffman wcale go tak nie definiuje. W jego szkicu Charakterystyka instytucji totalnych czytamy bowiem o pięciu rodzajach takich miejsc: 1 . ,instytucje powołane do opieki nad osobami niedołężnymi i nieszkodliwymi”; 2. „zakłady opieki nad osobami niezdolnymi do samodzielnego troszczenia się o siebie, a zarazem - choć nie z ich winy - niebezpiecznymi dla społeczeństwa”; 3. przestrzenie, „których zadaniem jest ochrona społeczeństwa przed szkodzeniem mu w sposób świadomy"; 4. ,instytucje [...] powołane do realizacji określonych zadań technicznych"; 5. ,,instytucje dla osób, które dobrowolnie wycofały się z czynnego życia, oraz miejsca kontemplacji religijnej" ${ }^{15}$. Najbardziej reprezentatywnym dla trzeciego typu będzie więzienie. Co ciekawe, zakłady penitencjarne, o których traktować mają wspomnienia Wata, nie spełniają stawianych im przez Goffmana warunków: ich zadaniem nie jest izolowanie jednostek niebezpiecznych dla społeczeństwa, lecz raczej zagrażających status quo państwa. Ich totalistyczne zapędy wynikają więc bezpośrednio z totalitarnego systemu, jakiemu zostały podporządkowane. Jednocześnie szpitale, najbliższe typowi pierwszemu, ale przez Goffmana do niego niezaliczone, są zdaniem Wata nierozerwalnie sprzężone z wizją świata „zza drutów”: stanowią nie tylko przestrzeń ograniczającą, osaczającą, ale także potencjalnie niemożliwą do opuszczenia. Pobyt w Kaiser Hospital naznaczony jest przekonaniem o zbliżającej się śmierci; wspomnienia innych placówek także koncentrują się wokół pacjentów odchodzących, zdanych na niełaskę medycznego personelu, w swojej śmierci absolutnie zdehumanizowanych (Wat obsesyjnie powraca do motywu kotar oddzielających pacjentów, maskujących śmierć). Szpitale to dla poety „umieralnie", o jakich pisał już w Maltem Rainer Maria Rilke:

Teraz umiera się w pięćset pięćdziesięciu dziewięciu [łóżkach - przyp. M.K.]. Naturalnie fabrycznie. Przy tak znacznej produkcji poszczególna śmierć nie jest wykonana szczególnie dobrze, ale nie o to przecież chodzi. O masę chodzi ${ }^{16}$.

${ }^{15}$ E. Goffman, Charakterystyka instytucji totalnych, thum. Z. Zwoliński [w:] Wspótczesne teorie socjologiczne, t. 1, oprac. A. Jasińska-Kania, L.M. Nijakowski, J. Szacki, M. Ziółkowski, Warszawa 2006, s. 316-317.

${ }_{16}$ R.M. Rilke, Malte. Pamiętniki Malte-Lauridsa Brigge, przel. W. Hulewicz, Warszawa 1979, s. 19. 
Wpisują się one zatem w Goffmanowskie wyobrażenie miejsca izolacji wyłączonego spod obowiązującego na zewnątrz prawa; jak czytamy w Charakterystyce instytucji totalnych:

[...] całe życie mieszkańców tych instytucji toczy się w jednym miejscu i podlega tej samej, jedynej władzy. [...] we wszystkich fazach codziennej działalności ich członkowie pozostają w bezpośrednim towarzystwie dużej liczby innych członków [...] cały dzień jest ściśle zaplanowany, jedna czynność w wyraźnie przewidzianym czasie przechodzi w drugą. Plan ten narzuca $\mathrm{z}$ góry system formalnych rozporządzeń, a jego przestrzegania pilnuje zespół nadzorców ${ }^{17}$.

Wat nieustannie podkreśla ,inność” przestrzeni szpitalnych; nie tylko opisuje je jako odmienne od codziennego doświadczenia, ale przede wszystkim chętnie na takie kreuje. Szczególnie wstrząsającym przykładem pozostaje wspomnienie gry, do jakiej stara się zmusić żonę Olę:

z[przy]muszaiłem żonę [Olę]

by wchodząc do mnie nakładał[a] maskę, kup[i]oną [dawniej] dla

smiechu w magazynie p sklepie potwornosci w s[S]an f[F]rancisco, $m$

Wchodziła do mnie z sią [zatem] optrehniętą [z] małą twarzą[yczką] cmentarbnicy Mrs Addams.

Dalej zaś dodaje w tym samym tonie:

Swiatło rąk ktpomoen ktore promieniuje poprzez czarne gumowe rękawiczki do ktorych [noszenia] przymusiłem moje otoczenie.

Intencja Wata pozostaje jasna: pragnie naznaczyć niegościnną, sterylną przestrzeń jeszcze większym piętnem inności. Poddanie się prawu instytucji nie wystarcza - pisarz celowo kreuje szpital Kaisera na instytucję totalną, w której obowiązujące na zewnątrz zasady współżycia zostają zawieszone. Czułość czy miłość okazują się emocjami zakazanymi; Wat chce uczynić z Oli obiekt, jakim on sam stał się w momencie przyjęcia roli pacjenta. Skoro jego wolność ograniczana jest nieustannie przez lekarzy (narzucających rodzaje kuracji) czy personel pomocniczy (wyznaczający pory wizyt, posiłków, dokonujący podziałów przestrzeni za pomocą żaluzji i parawanów), pragnie on wydostać się z roli uciemiężonego, stając się opresorem. Zmusza żonę do zakładania przebrań; co istotne, nie są one przypadkowe ani bez znaczenia. Dyskomfort, jaki wywołuje w Oli konieczność noszenia groteskowych, stylizowanych na przerażające masek, pozostaje wiadomy samemu poecie.

Moja biedna żona? s[S]erce mi się scisk litoscina [na] widok tej[go] obrzmiałej[go] sinej[ego] [czułego] arzyezki [liczka]. M cudzejAle [co z tego! Co z tego! Co $\mathrm{z}$ tego!] żrenice były nadal nagie i przez eałą m[M]iłość i e[C]zułość i 1[L]ito przebijały mnie jak [ruchome] noże.

${ }^{17}$ E. Goffman, Charakterystyka ..., s. 317. 
Jednocześnie wszelkie pozytywne emocje wywołują w pacjencie dodatkowe cierpienie. Miłość, czułość i litość odczuwane przez Olę stwarzają bowiem granicę pomiędzy możliwościami człowieka zdrowego oraz chorego; są głosem świata „zza murów”, świata niepodporządkowującego się prawidłom szpitalnym. Wat traktuje je jak przywilej, którego został pozbawiony. Jedyne, co może robić, to być beneficjentem pozytywnych afektów. Czuje się uprzedmiotowiony do tego stopnia, że wszelkie przejawy dobrej woli odbiera jako formę opresywnej opieki, podkreślającej jedynie jego bezużyteczność i nieporadność. Subwersywnie walczy z nią poprzez upokarzanie opiekunów: zmuszanie ich do odgrywania groteskowych ról żałobników, celowe umieszczanie w sytuacjach dyskomfortu i niedecydowania o sobie samym. Ola, odwiedzając szpital, godzi się na przyjęcie do wiadomości śmierci męża przychodzi do niego jako „cmentarnica”, istota wewnętrznie również martwa. Włączenie jej i personelu do gry redefiniuje na nowo miejsce: infirmerium ${ }^{18}$ staje się przestrzenią naznaczoną obecnością gnicia i rozkładu ciała; śmierć, tak skrzętnie ukrywana pod pozorami sterylnej dbałości o porządek, zostaje wprowadzona niejako tylnymi drzwiami, codziennie przynoszona przez rodzinę i bliskich, infekująca sale szpitalne.

Wat dokonuje w zapiskach z Kaiser Hospital ciekawego odwrócenia. $Z$ jednej strony opisuje czystość i komfort, jaki daje pobyt w takiej placówce. $Z$ drugiej zaś - zawsze są to sarkastyczne przytoczenia słów Oli. Zupełnie jakby przerzucał na nią odpowiedzialność za dokonanie oceny szpitala i wyśmiewał sposób postrzegania właściwy osobie z zewnątrz:

Każdy dźwięk ranil moj mozg obnszony jak swiatlo smagało moje obns

Jak swiatło smagało moje obnażone nerwy, tak dzwiek ra kaleczył moj[ą] [?] mozg przymusiłem moich bliskich by szept [?] przełożyli na mowę gestow ę at [lecz] moj cortex [?] fgresty interpretowal [?] jako [na] dzwięki konałem z i zno konałem $\mathrm{z}$ mdłosci i bolu.

$\mathrm{O}$, moje mdłosci, nie jadł z jadła ale $\mathrm{z}$ ust sroganck bezczel wytywających lubirżnych skłonnych do kazdej nieczystosci, moj i jelita rozkoszuj znajdujące w gniciu, w smrodzie, rozgładu i kale, o to ciało obmierzłe poddane gniciu, tn szkielet podd prochnieniu. [I] Z ubytkiem ciała ropuchła moja mizantropia. Swiatło i dzwięk. s on et lumiere. (...)

Takiego odwoziś do szpitala. Moja czuła dzielna żona [,] miły pan MIee, przyznajeie się, mysleliscie, że to ostatnia sze mn przejańdńka. (...) Szpitale seria moich szpitali. To szczęscie - mowi Ola e ktory dobrze poznała je wsztkie [,] z wyjąt-

${ }^{18}$ Iwona Boruszkowska posługuje się pojęciem infirmerium na określenie nie tylko konkretnego miejsca (etymologicznie francuskie infirmerie oznacza salę dla chorych, pochodzi zaś od łacińskiego infirmus: słaby, chory), lecz także swoiście pojmowanej poetyki mu przynależnej i przez nie generowanej. Kategoria ta w jej optyce bliska jest prezentowanemu tu ujęciu instytucji totalnej i nakłada się momentami na Foucaultowskie definicje heterotopii. Z jednej strony stanowi ona - najogólniej rzecz ujmując - ,pole doświadczenia medycznego", miejsce przejawiania się symptomów chorobowych oraz ich terapii, z drugiej zaś okazuje się przestrzenią zamieszkiwaną przez podmiot słaby, podatny na opresywne działanie hierarchii i odgórnie regulowanych praw. 
ki dwuch [?] pirwszych więziemych, - że masz [będziesz miał] tu taki komfort! te roże [bielizna] poscielowa, [każdego ranka] na o 8] rozowa zaslona ogradzjąca ofd sąsiada, te rozowe [ciemniejsze o 2 tony] deszczułki żaluzji $\Theta$ [co] rano odmykane [?] obracan na sztorc bym mogła eglądá [patrzeé zwrócić chore oczy na] magnolię [?] soezysteym zielonym lis i trawnik zielony i pyszne [?] kalifornijskie niebo niedysltetne ę te blaski [?] i swiatta ktore mnie przyprawiająo mdloset.

Pozór wytwarzany przez personel medyczny (codzienna zmiana bielizny pościelowej, różowe kotary oddzielające pacjentów, wzmagające wrażenie posiadania przestrzeni prywatnej, okna z widokiem na park), niedostrzegalny dla Oli, dla samego pisarza wydaje się oczywisty. Totalność instytucji ustanawia niepodlegające dyskusji zasady: magnolię można zobaczyć tylko wówczas, gdy ktoś inny odsunie żaluzje; ustawiony parawan zaś odbiera nam możliwość ujrzenia twarzy osoby leżącej obok, ale nie izoluje od jej głosu i głosu jej ciała. Cisza i ciemność są reglamentowane; chory znajduje się w przestrzeni nieoswajalnej i wybiera tym samym wygnanie w głąb własnej somy: skazany na nieustanną opresyjność dźwięków oraz świateł, zostaje przez nie zapędzony do wnętrza swojego bólu. Dehumanizacja przestrzeni zewnętrznej zmusza więc pacjenta do zamieszkiwania przestrzeni wewnętrznej. Tym samym sala przeobraża się w celę: infirmerium zostaje zinternalizowane ${ }^{19}$.

Teraz to ciało, poddawane ciągłym ,zabiegom” i wtłaczane w schematy funkcjonowania przestrzeni infirmeryjnej, staje się idealnie szczelną salą chorych. Jak słusznie zauważa Iwona Boruszkowska w swoich analizach przestrzeni infirmeryjnych, ,nie ulega wątpliwości, że psychofizyczny podmiot umiejscowione ciało i ciało jako przestrzeń - wchodząc w relacje z miejscem i samo będąc przestrzenią, pozostaje zwornikiem infirmeryjnych analiz"20. W nim zaś wszystkie znaki „komfortu” ulegają odwróceniu: światła, przyprawiające Wata o mdłości, stwarzają kanał dla owych mdłości fizycznego uobecnienia. Tekst przybiera formę kolistą, staje się wiecznie otwartym przejściem między zewnętrzem i wnętrzem, granicą, na której balansuje podmiot skazany. Zinternalizowane infirmerium jawi się jako obraz szpitala à rebours. Zamiast jasności pojawia się ciemność zaszytego worka skóry; czystość zostaje zastąpiona nieczystością gnicia, rozkładu i kału. Interpretacja sygnałów napływających z rzeczywistości trafia w ręce usamodzielnionego oraz uniezależnionego

19 Postawa Wata nie koresponduje bezpośrednio z żadną ze wskazanych przez Goffmana technik adaptacyjnych. Wycofanie się w głąb ciała mogłoby teoretycznie służyć ,wycofaniu się z sytuacji”, czyli technice regresji, jednak internalizacja infirmerium prowadzi do jeszcze większego - choć tym razem uwewnętrznionego - wyobcowania z przestrzeni totalnej (zob. E. Goffman, Charakterystyka..., s. 325).

${ }^{20}$ Cytat jest niepublikowanym fragmentem rozprawy doktorskiej, nad którą Boruszkowska pracowała na Wydziale Polonistyki UJ. Pochodzi z rozdziału w całości skupionego wokół tematyki infirmeryjnej zatytułowanego Tekst infirmeryjny albo topografia doświadczenia medycznego. 
już od reszty „cortexu”21: to kora mózgowa decyduje o tym, co wywoła ból, jakie - pozornie neutralne - bodźce okażą się zabójcze dla percepcji pisarza. Część mózgu staje się tym samym strażnikiem celi, kolejnym, uwewnętrznionym już opresorem, nad którym Wat absolutnie nie posiada kontroli. Wszystkie zabiegi, by oszukać okrutnego decydenta (zmuszanie rodziny do szeptu), zostają zdemistyfikowane; szanse na odzyskanie wolności we własnym ciele - zaprzepaszczone.

Opresyjność przestrzeni infirmeryjnej ujawnia się zatem zarówno na zewnątrz (w praktykach personelu niezależnych od woli pacjenta) oraz wewnątrz (w samym, wyobcowanym we własnym ciele, chorym). Zamknięcie w niej Wata okazuje się wyrokiem analogicznym do osadzenia w więzieniu - komplementarność tych dwóch przestrzeni staje się coraz bardziej dojmująca $^{22}$. Ich dystopijny charakter zbliża je zatem do kategorii ukutej przez Michela Foucaulta: więzienie oraz infirmerium to awers i rewers tej samej heterotopii, w której podmiot zostaje zaklasyfikowany jako dewiacyjny, odmienny, odstępujący od normy ${ }^{23}$. Narzucona mu wizja własnej osoby wpływa na sposób postrzegania swojego ciała i jego reakcji. Wat brzydzi się go; jak mogliśmy zobaczyć w poprzednio cytowanym ustępie, skupia się na jego biologicznym rozkładzie. Dodatkowo zauważa, że zbuntowana soma czerpie przyjemność z jego bólu (,jelita rozkoszuj znajdujące w gniciu, w smrodzie, rozgład i kale") - to, co w podmiocie zdrowym wywołuje odrazę, ,ja" defektywne przekuwa w rdzeń i sens swojego istnienia.

Różnica, jaka wytwarza się pomiędzy analizującym swoją sytuację i ją opisującym podmiotem tekstowym a poddanym procesom uprzedmiotowienia i gnicia podmiotem defektywnym, jest w notatkach z Kaiser Hospital porażająca. Wat opisuje samego siebie jako obcą rzecz, której nie rozpoznaje nawet jako części własnej osoby. Jest ona czymś zdeformowanym, niepełnym, ułomnym. Nie-martwym, ale też nie-żywym: niemożliwym właściwie do jakiegokolwiek zaklasyfikowania. Przypomina słynne istoty o niepewnym statusie ontologicznym zaludniające wiersze z cyklu $Z$ naszeptów magnetofonowych:

${ }^{21}$ Autonomia „cortexu” stanowi bardzo istotny motyw także w Dzienniku bez samoglosek. W notatce z 7 czerwca 1964 r. czytamy: „A teraz mam poddać się autonomii cortexu mojego ujarzmionego, wyalienowanego $\mathrm{z}$ tego co tymże mózgiem uważam i odczuwam za swoją osobowość. Co za opętanie haniebne i nie ma nie ma wiary i nie będzie patronki ani egzorcysty żeby mnie z tej diabelskiej niewoli wyzwolić" (wersja rozszyfrowana przeze mnie na podstawie oryginalnego maszynopisu przechowywanego w Beinecke Library: Aleksander Wat Papers, Series II: Writings, Box 12, Folder 380 [GEN MSS 705]).

${ }^{22}$ Por. $\mathrm{z}$ fragmentem notatek, w którym Wat zestawia szpitalną opaskę z kajdankami: „Tymczasem znałazłjdu jestem zatem w szpitalu i po zakładujł mi na rękę pobrączką z plastykow u jak łancueszek policyjny takie odbieram wrażenie aby nie pomyliś mnie $\mathrm{z}$ innym nieprzytomnym lub zumarłam".

${ }_{23}$ M. Foucault, Inne przestrzenie, przeł. A. Rejniak-Majewska, „Teksty Drugie” 2005, nr 6, s. 121-122. 
Ten nie-sen senniejszy niż sen.

Miąższ gorącego bólu. Ale już zagarnia cię fala, rozległa, z daleka, oddech jej przypływów-odpływów. Rytuały:

w jaki znak ułożysz kościane palce

na krochmalonym płótnie?... A teraz znów zaśnij,

niedoszkielecie ${ }^{24}$.

W przywołanym liryku-fragmencie pojawia się „niedoszkielet”: coś, co nie jest jeszcze trupem, ale nie sposób zaliczyć go też do świata żywych. Analizując naszepty magnetofonowe i ich fragmentaryczność, wskazywałam na bardzo ważną funkcję owych ,istot pośrednich” dla wyobraźni Watowskiej:

Wat wprowadza nas tym samym do świata b y tó w pośr e d n i c h, przez nikogo niechcianych i nieakceptowanych; takich, które same posiadają status f r a g m e n t u. „Niedoszkielet” to bowiem niedoszły szkielet, umierający, zawieszony między życiem a śmiercią. Cząstka „niedo-” uobecnia także inne skojarzenia: $\mathrm{z}$ wyrazami „niedorobiony”, „,niedostateczny”. Postać z Ten nie-sen ... nie tyle jeszcze nie przekroczyła progu, do którego się zbliża; można by raczej zaryzykować tezę, iż umarła ona źle, niezgodnie $\mathrm{z}$ obowiązującą procedurą. Nie należy więc już ani do świata ludzi, ani nieboszczyków - trwa zawieszona nie pomiędzy możliwościami, ale w nigdzie. Nie rozpościera się przed nią żadna przyszłość, a przeszłość pozostaje radykalnie zamknięta i obca. „Niedoszkielet” do nikogo i do niczego nie przynależy, jego egzystencja wydaje się czystą negatywnością ${ }^{25}$.

„Niedoszkielet” pasuje więc do przestrzeni heterotopicznej, o której Foucault pisze, iż jest miejscem poza wszelkimi miejscami ${ }^{26}$ : nie sposób jej konkretnie usytuować (nawet jeśli niekiedy da się wskazać ją na mapie) ani precyzyjnie uchwycić dyskursywnie jej charakteru. Byt pośredni - jakim w naszeptach jest metaforyczny nie-do-byt, a w notatkach z Kaiser Hospital sam pacjent - nie znajduje dla siebie miejsca w świecie „oznaczonym”, poszukuje go więc na marginesach, poza zasięgiem zdrowego wzroku, w szczelinach. Najpełniejsza definicja heterotopii dana przez Foucaulta w Innych przestrzeniach sprowadza się do kilku enigmatycznych zdań:

Są też, prawdopodobnie w każdej kulturze, w każdej cywilizacji, miejsca (lieux) rzeczywiste - miejsca, które wyznaczane są wraz z tworzeniem się społeczeństwa, które są czymś w rodzaju kontr-miejsc (contre-emplacements), rodzajem efektywnie odgrywanej utopii, w której wszystkie inne miejsca (emplacements), jakie można znaleźć w ramach kultury, są jednocześnie reprezentowane, kontestowane i odwracane ${ }^{27}$.

${ }^{24}$ A. Wat, Poezje zebrane, s. 417.

${ }_{25}$ M. Kmiecik, Drogi negatywności. Nurt estetyczno-religijny w poezji i muzyce awangardowej w XX wieku, Kraków 2016, s. 257.

${ }^{26}$ Zob. M. Foucault, Inne..., s. 120.

${ }^{27}$ Ibidem. 
$\mathrm{Z}$ jednej strony dowiadujemy się, że heterotopie nie są abstrakcjami: możemy zlokalizować je w intersubiektywnym doświadczeniu jako szpitale, cmentarze czy sanatoria. $Z$ drugiej jednak, stanowią one rodzaj persyflażowej utopii, odwrócenia porządku symbolicznego obowiązującego w ramach przyjętych norm społecznych. Podobnie jak w notatkach Wata, wszystkie pozytywne walory heterotopii (szpitalny komfort podkreślany przez Olę) ujawniają się we własnym ironicznym wykrzywieniu, w istocie odsyłają do swoich przeciwieństw. Opieka staje się opresją, uprzejmość - dyktatem, różowa kotara - ścianą celi ${ }^{28}$. Kontr-miejsca nie pozwalają na jakiekolwiek zakorzenienie, wyrywają człowieka z jego codziennej, ustabilizowanej tożsamości i zmuszają do jej porzucenia. Nie oferują jednak żadnej innej identyfikacji; pacjent szpitala, chory stanowi bowiem jedynie element systemu, traci swoją jednostkowość i nie odnajduje w nowym miejscu nowego ,ja”. Podmiot skupiony na własnym defekcie jest dla Wata podmiotem ułomnym, nieukonstytuowanym, pośrednim. Jeśli gdzieś się umiejscawia, to tylko w kontrze do swojego poprzedniego ,ja".

Watowskie szpitale przybierają jednak różne formy; demoniczność Kaisera bierze się przede wszystkim z jego absolutnej dehumanizacji. Pisarz, wspominając pobyty w lecznicach więziennych czy rosyjskiej placówce w Ili, odnosi wrażenie, że posiadały one - mimo okropnych warunków sanitarnych - ludzki charakter:

O jak ja zatęsknilem za moimi starymi nędzarskim szpitalami??! Moj szpital więzienny w SAratowie i doktor nacz ktory codzien wstydliwieOkładl na stoliku D przezroczystego jak nieo z niedojadania ascetycznie przezroczystego z nakazanego sobie postu Mor Dsenatora z RYgi Du mordec Dubiana a p kilka nmarchewek gd zi cel i czosnek po ba czerwone opo mocno czerwone pomidory fgdie ion je zdo a potem i mnie je przynosią może dlatego że bylismy jedynymi tu cudzo ami alr nie przez snobizm ę przez wstyd za jego Rosję, o znałe widział nieraz ten piekący wstyd ktory przekształca si w szlochanie gd moj przyjacielowi i guiumierającem na grużlicę iopowiedziałem moje Szanejsde z pas przebeg paszportyzacji. Moj szpital W ili sala gdzie ja miałe najłepsze przy oknie wychodzącym na dzr patrzącym n wielko rozłożysty klon bardziej rozłożysty mniz ta tutaj magnolia gdzie pomiędzy 22 moimi wspolciep na tej sali so mtr kw krążyła jedyny tu basen błaszan osmiu dzrew rozległego miasteczka, to łożku z chudym suennikem z przesyconym zapavhem kału hgrubym spranym plamistym i moczu przscieradłem na hktorym podrzucało mnie w strasznej długiej prwiw pr już przedsmietrmej konwulsji dała mi krew tę kt Gdy doktor LIubow IS nadała mi krew jedyną jaką tu mi była i kas tjak i kaszkę manną z włas deputatu i arbuza, nic innego nie miała i mleko i.

W odróżnieniu od Kaisera, lekarze okazywali tam pacjentom dużo serca i zrozumienia, dzielili się własnymi racjami żywieniowymi, walczyli o ich życie nieortodoksyjnymi metodami (Watowi przetoczono w Ili krew innej gru-

${ }^{28}$ Por. $\mathrm{z}$ fragmentem: „Przez czułosc dobroc miłose [miłosierdzie] przebiają okrucienszw nie ich, okriucienstwa 
py) - mimo że reprezentowali „system” instytucji totalnej, wciąż pozostawali w nim czującymi istotami. Nie mieli w sobie nic ze zmaszynizowanych ruchów, gestów i wypowiedzi amerykańskiego personelu. Innymi słowy - byli tak samo opresjonowani przez system szpitalnej heterotopii, jak podlegający im chorzy; nie utożsamiali się z jego bezdusznymi podziałami i nie separowali się od pacjentów jako elementów dewiacyjnych, skażonych.

Kaiser Hospital natomiast wciela zasadę wskazywaną w końcówce eseju Foucaulta; jego zadaniem jest tworzyć

[...] przestrzeń iluzji [...] która jest inna, inną realną przestrzeń, tak doskonałą, dokładną, tak dobrze uporządkowaną, jak nasza jest nieporządna, źle skonstruowana i pomieszana ${ }^{29}$.

Przeniesienie pacjenta w sztuczne i w całości wykreowane miejsce, naśladujące i jednocześnie prze-śladujące (w sensie zbyt dokładnego i precyzyjnego zrekonstruowania, które daje nam poczucie życia w specjalnie dla nas zaprojektowanej oraz wykonanej klatce), odbiera mu jego zdolność działania (sterując nim), ale - co bardzo ważne w kontekście notatek z Kaiser Hospital - zdaje się też odbierać mu zdolność mowy. Autobiografia heterotopiczna, jaką próbuje naszkicować Wat, okazuje się tym samym bełkotliwa, a wręcz nieczytelna. Zupełnie jakby pisano ją z zakneblowanymi ustami i skrępowanymi dłońmi.

\section{Poetyka heterotopii a rozkład języka: archiwum jako miejsce uobecniania się podmiotu defektywnego}

W Innych przestrzeniach Foucault wylicza pięć najważniejszych cech heterotopii. Są to przestrzenie, w których ,sytuowane są jednostki o zachowaniu dewiacyjnym w stosunku do przeciętnego czy wobec wymaganej normy"30; zestawia się w nich z sobą „liczne przestrzenie, liczne miejsca (emplacements), które są ze sobą niekompatybilne"31; które zaczynają „funkcjonować w pełni wtedy, gdy ludzie znajdują się w sytuacji absolutnego zerwania ze swoim tradycyjnym czasem"32 (tzw. heterochronie); posługują się też specyficznym systemem „otwarcia i zamknięcia, który jednocześnie izoluje je i czyni przepuszczalnymi”"33. Ostatnia cecha, o której już wspominałam, odsyła zaś do iluzji i deziluzji: ma kompensować chaotyczność zewnętrznej rzeczywistości lub tworzyć jej wierną, ale całkowicie sztuczną kopię. Co wydarzyłoby się jednak, gdybyśmy spróbowali te właściwości przenieść w dziedzinę poetyki, jako przykład ,„pisania heterotopicznego" wskazując notatki z Kaiser Hospital?

\footnotetext{
29 M. Foucault, Inne..., s. 124.

30 Ibidem, s. 121.

31 Ibidem, s. 122.

32 Ibidem, s. 123.

33 Ibidem.
} 
Pierwsza, najczęściej podnoszona właściwość, odsyłałaby nas z pewnością do wyobrażenia języka chorobowego czy dewiacyjnego, nienormatywnego. W przypadku Wata owa „nienormatywność” ujawnia się w pierwszej kolejności w zaburzeniach składni. Już w pierwszych akapitach czytamy:

Drugim następstwem był i jest nieporządek, zasdniczy podstwaowy gruntowny we wstkim bez wyjątku nieporządek nieporządek mysli, które to galopują z taką szybkoscią, że napr próżno by tu mysleś o zapisie nawwet w tej zdawkowo skroconej nieswoiscie stenografixznej urwanej i żadnej (pozbawionej swego k ksztaltu u i wolumeni postaci, ktorym wypełniłem setki kartek str ronic karteluszkow swistkow, bez pożytku, nie do odcyfrowania dniekiedy nawet sla mnie samego. A T; to znow słAbła i konała w zupełnej stagnacji, nieporadna, nieruchawa, niepomiernie ciężka, nie do pruszenia jak s matwy gnijąca woda w cysternie nakryta rzęs w ktorej już nie poruszją się senne ropuchy.

Uwagę czytelnika zwraca przede wszystkim forma enumeracyjna przywołanych zdań: pojawia się w nich mnóstwo redundantnych epitetów (,zasdniczy podstwaowy gruntowny”, „nieporadna, nieruchawa, niepomiernie ciężka, nie do pruszenia jak s matwy gnijąca"), których zadaniem jest jedynie wywoływanie efektu gradacyjnego, rozrastania się, samopączkowania mowy. Wat konstruuje swoją wypowiedź w taki sposób, aby czytelnik miał wrażenie nadmiaru elementów, ich nagłego wyłaniania się z coraz mroczniejszych zakamarków świadomości piszącego. Jednocześnie wyliczenie prowadzi go na manowce sensu: ostatnie zdanie traci w pewnym momencie swoją logiczną strukturę. W „nie do pruszenia jak s matwy gnijąca woda w cysternie nakryta rzęs” nie wiadomo, co oznacza słowo „matwy”. Z kontekstu spodziewamy się wyrazu „martwy”, ale wówczas musielibyśmy założyć nieoczekiwane urwanie wypowiedzenia (w wersji poprawionej brzmiałoby ono: „nie do poruszenia jak martwy gnijąca woda”). „Gnijąca woda” gramatycznie pochodzi z innego porządku, chyba że założymy, iż Wat chciał użyć formy „martwa”, a wieńczącą słowo literę y zaklasyfikujemy jako najzwyklejszą literówkę. Być może jednak błąd tkwi w innym miejscu i pisarz chciał zanotować wyraz ,mątwy”, by wprowadzić nas w zupełnie inne (podwodne) imaginarium, z którego w ostatniej chwili zrezygnował. Wówczas „mątwy” wymagałyby wykreślenia, a zdanie po korekcie brzmiałoby: „nie do poruszenia jak gnijąca woda w cysternie nakryta rzęsą". Składniowe niekonsekwencje wynikają z faktu, że Wat bardzo często nie nanosił poprawek na maszynopis; zrywając tok zdania i zastępując je nowym wypowiedzeniem, nie wykreślał fragmentów „porzuconych”. Tworzył tym samym w szkicach efekt ,polifoniczności”, współistnienia rozmaitych głosów, które zostają odnotowane jako ,potencjalne”, nigdy nieuobecnione.

Nienormatywność Watowskiego pisma przekładałaby się zatem od razu na drugą z cech heterotopii: zestawiania z sobą licznych przestrzeni. Wielotorowość notatek z Kaiser Hospital, istnienie w nich niekompatybilnych i nieuzupełniających się ścieżek myślenia, stanowi świadectwo przebywania w prze- 
strzeni, w której nakłada się na siebie wiele niespójnych historii. Wat niejako notuje (czy też zaczyna szkicować) każdą z nich; nie ma jednak możliwości wszystkich uzupełnić. Pozostawia więc w tekście ślady zerwanych narracji na wzór tropów: podążanie za nimi pozwala rekonstruować nigdy niewybrzmiałe metafory (pojawiająca się jako echo „mątwa” odsyła nas w bardzo wiele rejonów znaczeniowych: świata podwodnej tajemnicy i ciemności, ale także świata zbrudzonego wytwarzaną przez te organizmy sepią). Nadaje to notatkom inny rodzaj g ę s t o ś c i - zaczynają one funkcjonować niejako palimpsestowo, uobecniając różne czasy i miejsca zapomniane czy już nieobecne.

Prowadzi nas to w stronę specyficznie rozumianej i konstruowanej przez pisarza heterochronii. W makroskali obserwujemy ją w maszynopisie jako przenikanie się obserwacji z różnych czasów: płynne przechodzenie od wspomnień z okresu rosyjskiego, polskiego i amerykańskiego. Zupełnie jakby szpital Kaisera mieścił w sobie wszystkie te inne, analogicznie doświadczane przestrzenie:

To szpital! Jabym nie wiedział co jest odpowiednie dla szpital Ja z moją praktyką nieomal cwiecwiekowycą, $\mathrm{z}$ na w czterech krajac w trzech już na trzech już kontynetacz, po s 16 ,hispitalizacjac Jabym nie oceniał doskonałosci pod każdym względem z wyjątliem teg jednego tak ważnego Kaiser Hospital, ja - po nuerol gi w warszaw ki Dzieciątka Jezus, gdzie pacjenci już z czkawką smiertelną leżel na korytarzach.

We wspomnieniach Wata wszystkie szpitale przybierają postać jednej, spojonej nierozerwalnie heterotopii. Inicjalna eksklamacja: „To szpital!” odnosi się zarówno do realnej przestrzeni Kaisera, jak i do wszystkich innych konotowanych przez to słowo. Wraz z poetą rozpoczynamy podróż przez cztery kraje i trzy kontynenty, zupełnie jakby odległości między nimi nie istniały, zostały zdestabilizowane przez więź symboliczną. Komentarz Wata możemy sprowadzić do prostej tezy, iż każda placówka, choć nie będzie wyglądać tak samo, powieli cechy instytucji totalnej. W samej tkance językowej ta tożsamość zostaje podkreślona wyrugowaniem interpunkcji. Wat zachowuje wielkie litery na początkach zdań, lecz rezygnuje z oddzielających je tradycyjnie kropek. Sygnalizuje więc przejście do następnej myśli (czy może raczej w kolejne miejsce), ale czyni je płynnym, celowo wymazuje granice między nimi.

Zaburzenia interpunkcji (szczególnie w przypadku niedomykania nawiasów czy cudzysłowów) bardzo często wskazują na swoistą „nieskończoność” Watowskiego dyskursu. Pisarz nie tylko przerywa toki narracyjne i pozostawia je w formie niedopowiedzianej, lecz także otwiera furtki dla nieustannego dopisywania kolejnych elementów ${ }^{34}$. Niedomknięty nawias sugeruje możli-

${ }^{34}$ Strategia ta występuje też w makroskali w postaci nawracających motywów. Przykładem może być motyw przebierania się Oli za Mrs Addams. Zostaje on w formie szczątkowej wprowadzony na stronie piątej (,Өłę pPrzymusiłem [żonę] by wchodząc do mnie kładła maskę cmentarnicy mrs ADdams") i jest rozbudowany w obraz poetycki w szkicu do wiersza *** Szanujący się kościotrup... na stronie ósmej. 
wość lepszego doprecyzowania, dalszej pracy nad kształtem tekstu. Mamy więc prawo traktować ten zabieg jako typowy dla brulionów. W notatkach z Kaiser Hospital staje się on jednak obsesją: zupełnie jakby Wat wierzył, że te quasi-otwarcia pozwolą wprowadzić do tekstu inne, jeszcze nieobecne w nich żywioły. Bruliony oczekują więc wtargnięcia obcych słów (być może pochodzących też od innych autorów, współuczestników szpitalnych doświadczeń), dla których nikt nie pozostawił miejsca. Pacjent, podmiot defektywny, wydaje się bowiem pozbawiony umiejętności mówienia, konstruowania zdań. Strategia Wata to zatem robienie miejsca dla mowy, która nie ma szansy wybrzmieć, otwarcie się na inne czasy i inne przestrzenie - jakich pisarz doświadcza w bólu, w niemocie, w odmowie komunikacji. Proza heterotopiczna staje się tym samym półprzepuszczalna (zgodnie z czwartym wyznacznikiem Foucaulta). Jest jednocześnie zamknięta (da się zrekonstruować jej tok narracyjny, odpowiednio manipulując skreśleniami i dopiskami) i otwarta (pełna zerwanych i niedomkniętych zdań). Gwarantem dostrzeżenia owej właściwości staje się też sposób zapisywania - pełen błędów, potknięć, luk i przekręceń.

Przyjrzyjmy się dokładniej jednemu fragmentowi:

Potem gdy kładę się podziwiamy wszyscy troje jak dzikusy lożko na ktorym leżę i ktore za pokręceniem rączkize zgrzytem zaczyna przybieraś ksztalzt dowolny załamiując się w trzech swoich stawach zaginajęc się wedle mojej chęci tak że miogę głowę podnies i zarazem nogi srodkową częśś cjialo opuszcza jak najniżej albo podni unies samą gorną cząsc treci ciała albo tylko s nogoi, mimo że umi konam za zmęczenia zabawiam się chwilę przerabianiem wsztkich możliwych figur.

Przy pierwszym czytaniu wydaje się on przejrzysty - mimo błędów możemy dostrzec sens zamknięty w akapicie, „wyizolować” go z całości. Błędy są typowe, nie zaburzają odbioru (np. ,przybieraś” zamiast przybierać, „załamiując” zamiast załamując, „częśś” zamiast część). Jednocześnie „przykrawane” wyrazy dostosowują się do warunkowanego poprawnie zapisanymi słowami rytmu tekstu, wprowadzającego do niego element naddany, niewłaściwy samym słowom. Passus ,albo podni unies samą gorną cząsc treci ciała albo tylko s nogoi” jest pełen przeinaczeń, jedyne zachowane w poprawnym brzmieniu słowa to albo, sama, ciała, tylko. One właśnie będą wyznaczały pierwotny rytm wypowiedzi; wszystkie mają dwie sylaby i zbliżoną liczbę liter (cztery lub pięć). Jeśli przeczytamy je, głośno skandując, fragment zyska walor mechanicznego powtarzania: zupełnie jakbyśmy obserwowali dźwięki wydawane przez prostą maszynę, której części unoszą się i opadają, ściskają i rozwierają, każdy ich ruch ma zaś charakter dwójkowy. Dodatkowo, żeby jeszcze mocniej oddać proces „zabawy” mechanizmem łóżka szpitalnego, Wat dzieli tę frazę na pół na jednosylabowym słowie „cząsc” - pięć słów dwusylabowych zostaje unieruchomionych na chwilę w tym wyrazie (oznaczającym zresztą najpewniej część, więc zwiastujących pewien rodzaj podziału), by potem znów podmiot wywołał ich szablonowe i schematyczne działanie. To ciekawe, że „spoiwo”, jakie wska- 
zuje, zostaje najmocniej zdeformowane; miejsce zatrzymania ruchu okazuje się tym samym semantycznym zgrzytem całej wypowiedzi. „Cząsc” konotuje cząstkowość, część, ale też czas. Wygląda niepokojąco, brzmi twardo (Wat gubi bowiem zmiękczone ś i ć), jak fragment jakiejś większej, zagubionej całości. Słowo zepsute staje się więc nie tylko zwornikiem, ale też punktem otwarcia, rozszczelnienia izolowanego sensu.

W cytowanym fragmencie owa półprzepuszczalność podkreślona jest też graficznie - poprzez lukę pomiędzy słowami „rączki” i „ze zgrzytem”. Oczywiście, zapewne pojawia się tam ona przypadkowo i moglibyśmy ją zignorować, co też czynimy w momencie przygotowywania tekstu do edycji. Studiując jednak bruliony Wata, nie sposób nie zauważyć dysonansu, jaki się dzięki niej wytwarza. Po jednej stronie pisarz stawia bowiem deminutywne „rączka”, po drugiej zaś przeciwstawione mu, onomatopeiczne i dźwiękowo nieprzyjemne ,ze zgrzytem”. Podkreśla tym samym dysproporcję między gładką gałką służącą do zabawy łóżkiem a nieprzyjemnym dźwiękiem wydawanym przez zmechanizowaną przestrzeń wyznaczoną dla pacjenta. Słowo „rączka”, będące metonimią, zrównujące przedmiot z częścią ciała, dodatkowo buduje sprzeczność pomiędzy somatycznym doświadczeniem oraz zdehumanizowaną przestrzenią jego przeżywania; między człowiekiem a szpitalem. Wat, rekonstruując w mowie heterotopię, pragnie uchwycić poczucie izolacji, zatrzaśnięcia $\mathrm{w}$ języku pojęciowym i w ciele odmawiającym posłuszeństwa (stąd pisanie $\mathrm{z}$ błędami, niepanowanie nad mięśniami własnych dłoni), a jednocześnie wykazać jej przepuszczalność, możliwość generowania niepodlegających normie sensów, które będą odsyłać nas do świata niedyskursywnego: przestrzeni somatycznej, audialnej, niepojęciowej.

Notatki z Kaiser Hospital powinniśmy więc czytać dwojako. Z jednej strony są one dokumentem biograficznym, uzupełniającym naszą wiedzę o życiu Wata w okresie kalifornijskim, o jego planach pisarskich i tekstach, nad którymi pracował (stąd liczne aluzje do Dziennika bez samogłosek czy szkic wiersza). Poświadczają one także stosunek poety do własnego życia oraz tworzenia autobiografii, naprowadzają na możliwości kategoryzacji wskazywane przez Goffmana czy Foucaulta, a także stanowią istotny głos w ramach literatury patograficznej czy infirmeryjnej. $Z$ drugiej strony, wydają się interesujące przede wszystkim jako świadectwo „mowy okaleczonej”, naznaczonej piętnem heterotopicznego doświadczenia przestrzeni choroby.

Analiza poetyki tekstu, przeprowadzona tu szkicowo, wydaje się jednak wyjątkowo interesująca w kontekście refleksji nad rolą archiwum w kształtowaniu się „koncepcji literatury” każdego pisarza ${ }^{35}$. Teksty niepublikowane i bruliony funkcjonowały przez wiele lat jako swoiste przedteksty rzeczywistych dzieł, ich formy niegotowe i niewarte pozafilologicznej uwagi.

${ }^{35}$ Pojęcie „koncepcji literatury”, jako szersze od poetyki i osadzające myśl twórczą w kontekście społeczno-kulturowym, defniuje Kees van Rees w artykule How Conceptions of Literature Are Instrumental in Image Building [w:] Institution and Innovation, red. K. Beekman, Amsterdam-Atlanta, GA 1994, s. 103-129. 
Przypadek fascynującego i bardzo bogatego archiwum Wata (myślę przede wszystkim o zbiorach zgromadzonych w Beinecke Rare Book \& Manuscript Library w New Haven) pokazuje jednak, że archiwum może stać się przestrzenią uobecnienia się zupełnie innego ,ja” twórczego, którego nie będziemy $\mathrm{w}$ stanie dostrzec $\mathrm{w}$ zedytowanych przez badaczy materiałach. Jeśli bowiem porównamy pieczołowite i bardzo dobrze udokumentowane rekonstrukcje eseistyki Wata opublikowane przez Krzysztofa Rutkowskiego jako Świat na haku i pod kluczem z materiałami archiwalnymi, zobaczymy dość szybko, z jak bardzo różnymi tekstami przyszło nam obcować. Dotychczasowe edycje dowartościowywały przede wszystkim zawartość myślową prac Wata i starały się oddać wiernie jego idee. Podejmowane dzisiaj w duchu krytyki genetycznej próby nowego „odczytywania” archiwaliów Watowskich ${ }^{36}$ pozwalają zaś na nowo prześledzić i przeanalizować ujawniające się w dukcie pisma, sposobie konstruowania notatek i pełnym niedociągnięć logicznych czy gramatycznych języku inne oblicze pisarza: jego ,ja” defektywne, naznaczone doświadczeniem bólowym, niekontrolujące już własnej pracy, nieposiadające jasno określonej twórczej tożsamości.

Notatki z Kaiser Hospital, jako że dotyczą bezpośrednio choroby Aleksandra Wata i stanowią jedno $\mathrm{z}$ bardziej przejmujących jej świadectw, tym bardziej mogą posłużyć za przykład pisma defektywnego, otwierając przed badaczami zbiory archiwalne jako przestrzeń, w której może się ono w sposób nieskrępowany manifestować. $\mathrm{W}$ przeciwieństwie bowiem do opresywnych heterotopii, brulion stwarza miejsce bezpieczne oraz intymne, w którym zarówno ból, jak i powolne z niego wychodzenie stają się równoważne i tak samo wartościowe. Dlatego właśnie notatki nie kończą się całkowitym rozproszeniem, ale nadzieją; nadzieją, jaką możemy pokładać również w innych, zwolnionych z obowiązku tworzenia przejrzystych sensów i estetycznych wartości, niedokończonych szkicach:

Chodzić,., ruezaé sStukać n[a] maszynie. ̇̇Żyć[?] [Żyć.]

\section{Bibliografia}

Boruszkowska I., Defekty. Auto/pato/grafie - szkice, Kraków 2016.

Foucault M., Inne przestrzenie, przeł. A. Rejniak-Majewska, „Teksty Drugie” 2005, nr 6.

Goffman E., Charakterystyka instytucji totalnych, przeł. Z. Zwoliński [w:] Współczesne teorie socjologiczne, t. 1, oprac. A. Jasińska-Kania, L.M. Nijakowski, J. Szacki, M. Ziółkowski, Warszawa 2006.

${ }^{36}$ Myślę przede wszystkim o znakomitym wydaniu części notatników Wata przez Adama Dziadka i Jana Zielińskiego (A. Wat, Notatniki, oprac. A. Dziadek, J. Zieliński, Warszawa 2015). 
Kmiecik M., Drogi negatywności. Nurt estetyczno-religijny w poezji i muzyce awangardowej w XX wieku, Kraków 2016.

Rees K. van, How Conceptions of Literature Are Instrumental in Image Building [w:] Institution and Innovation, red. K. Beekman, Amsterdam-Atlanta, GA 1994.

Rilke R.M., Malte. Pamiętniki Malte-Lauridsa Brigge, przeł. W. Hulewicz, Warszawa 1979.

Wat A., Mój wiek. Pamiętnik mówiony, t. 1, Warszawa 1990.

Wat A., Notatniki, oprac. A. Dziadek, J. Zieliński, Warszawa 2015.

Wat A., Poezje zebrane, oprac. A. Micińska, J. Zieliński, Kraków 1992. 